\title{
Recognition of cryptic species in the Asplenium nidus complex using molecular data - a progress report
}

\author{
Yoko Yatabe and Noriaki Murakami
}

\begin{abstract}
Yatabe, Yoko and Murakami, Noriaki (Department of Botany, Graduate School of Science, Kyoto University, Kitashirakawa-Oiwake-cho, Kyoto 606-8502, Japan) 2003. Recognition of cryptic species in the Asplenium nidus complex using molecular data - a progress report. Telopea 10(1): 487-496. Asplenium nidus is an epiphytic fern species with large simple leaves found throughout the Old World tropics. A large amount of variation of $r b c \mathrm{~L}$ sequences found in plants identified as $A$. nidus sensu Holttum (1974), suggested that multiple cryptic species might be within this species. We tested this hypothesis using $r b c \mathrm{~L}$ sequences. In previous studies, we found five $r b c \mathrm{~L}$ sequence types from populations of $A$. nidus in West Java, Indonesia. Based on ecological comparison and allozyme analysis, it is suggested these five $r b c L$ types may be potential cryptic species. Crossing experiments among these $r b c \mathrm{~L}$ types revealed that they are also reproductively isolated. Here we extend the investigation area from West Java to the West Malesian region in order to evaluate furthur the species diversity in the $A$. nidus complex. In this paper, we review our previous studies on recognition of cryptic species in the $A$. nidus complex and report our recent progress.
\end{abstract}

\section{Introduction}

In systematic research on the homosporous ferns, data from cytotaxonomic and enzyme electrophoretic studies have uncovered cryptic species in many lineages such as Adiantum, Botrychium, and Pityrogramma (see Paris et al., 1989). Recently, in various fern species such as Asplenium nidus, Hymenasplenium obliquissimum, H. cheilosorum (Aspleniaceae), Stegnogramma pozoi (Thelypteridaceae), Osmunda cinnamomea, O. claytonia, O. regalis (Osmundaceae) and Cheiropleuria bicuspis (Dipteridaceae), a large amount of $r b c \mathrm{~L}$ sequence variation has been reported (Murakami et al. 1998a, Murakami et al. 1998b, Yatabe et al. 1998, Yatabe et al. 1999, Kato et al. 2001). The substitution rates of $r b c \mathrm{~L}$ in Osmundaceae were estimated to be on average approximately $7 \times 10^{-8}$ nucleotide substitutions per year (Yatabe et al. 1999). Considering this slow evolutionary rate for $r b c \mathrm{~L}$, the large amount of $r b c \mathrm{~L}$ sequence variation within a single morphological species may suggest that these species contain several cryptic species that are reproductively isolated from each other. Here we have tried to recognize cryptic species in ferns using chloroplast DNA, including $r b c \mathrm{~L}$ sequences in Asplenium nidus.

Asplenium nidus is assigned to Asplenium sect. Thamnopteris, a group of epiphytic ferns with simple leaves, found throughout the Old World tropics. In this group, only tetraploid species $(2 \mathrm{n}=144)$ have been recorded so far (Bir 1960, Abraham et al. 1962, Koul 1970, Kawakami 1970, Tsai \& Shieh 1983, Yatabe et al. 2001). Murakami et al. (1999a) examined $r b c \mathrm{~L}$ sequences of this group and found that the difference among $r b c \mathrm{~L}$ sequences reached $4-5 \%$ in plants identified as $A$. nidus sensu Holttum (1974). We tested the hypothesis that $A$. nidus may contain several cryptic species using $r b c \mathrm{~L}$ sequences as a first step. In West Java, five $r b c \mathrm{~L}$ sequence types were found from plants 
identified as A. nidus according to Holttum's (1974) classification (Murakami et al. $1999 b$ ). We call these $r b c$ L types A, B, C, D and E. From phylogenetic analysis, these five $r b c \mathrm{~L}$ sequence types turned out to be distantly related in Asplenium sect. Thamnopteris (Murakami et al. 1999b, Fig. 1). If each $r b c$ L sequence type is a biologically distinct assemblage, we can conclude that $A$. nidus contains several cryptic species.

In order to clarify whether these $r b c \mathrm{~L}$ types are ecologically differentiated, their habitats were compared. The results suggest that the habitats of these five $r b c \mathrm{~L}$ types differ in altitude or in the position where they grow on the tree trunk, although the boundaries of the habitat were not necessarily clear (Murakami et al. 1999b, Yatabe et al. 2002, Fig. 2). In order to clarify whether $r b c L$ sequence types are genetically differentiated in their nuclear genomes, we examined allozyme polymorphism using the Single Strand Conformation Polymorphism (SSCP) method. The results showed some loci where the allele frequencies significantly deviated from each other for every pair of the $r b c \mathrm{~L}$ types (Yatabe et al. 2002). Nei's genetic distance (D) and genetic identity (I) were also calculated among rbcL types (Table 1). Soltis and Soltis (1989) reported the range of genetic identity (I) between congeneric species to be $0.00-0.85$, and between conspecific populations of homosporous pteridophytes to be $0.78-0.996$. All of the genetic identity (I) estimated fell into the range of that between congeneric species though the value estimated between Type $C$ and $E$ fell into the range of that between conspecific populations as well. Thus, it is suggested that the five $r b c \mathrm{~L}$ types distributed in West Java are ecologically and genetically well differentiated, separate species.

Table 1. Genetic Identity (above diagonal) and genetic distance (below diagonal).

$\begin{array}{lrrrrr} & \text { A } & \text { B } & \text { C } & \text { D } & \text { E } \\ \text { A } & - & 0.599 & 0.702 & 0.596 & 0.659 \\ \text { B } & 0.513 & - & 0.621 & 0.379 & 0.693 \\ \text { C } & 0.353 & 0.476 & - & 0.401 & 0.806 \\ \text { D } & 0.517 & 0.970 & 0.913 & - & 0.516 \\ \text { E } & 0.417 & 0.366 & 0.215 & 0.663 & -\end{array}$

Yatabe et al. (2001) also conducted artificial crossing experiments among rbcL types. These artificial crossing experiments were designed to examine the frequencies of hybrid formation, and the allozyme polymorphisms were used to identify hybrid plants based on their heterozygous patterns combining those of their parents. Details are provided in Yatabe et al. (2001). The results of five data sets showed that the pairing of Type A and B fail to form hybrid plants and that these are reproductively isolated. It has also been suggested by the results of the same artificial crossing experiments that hybrid plants may not be formed between Type A and C (Yatabe et al. 2001), B and C, and C and E (unpublished data). Thus, the plants classified as $A$. nidus consist of several cryptic species, and $r b c \mathrm{~L}$ sequences are useful as a first step to recognize cryptic species in $A$. nidus.

It becomes, however, more difficult to interpret the molecular data when we extend our investigation area and take the allopatric populations into consideration. Now we are investigating cryptic species distributed in West Malesia as well as West Java. In order to clarify the distribution of the potential cryptic species found from West Java, it is necessary to investigate the distribution of the $r b c \mathrm{~L}$ types in areas adjacent to West Java. In this paper, we report the results of investigation at two areas in West Malesia, the Malay 
Peninsula and West Sumatra (Fig. 1). By comparing the habitats of rbcL types distributed in the Malay Peninsula and West Sumatra, we addressed the following questions: 1) Is ecological differentiation observed among $r b c L$ types in these areas as well as West Java? 2) Do individuals of the same $r b c \mathrm{~L}$ type keep their habitat preference constant throughout their distribution area?

\section{Materials and Methods}

\section{Materials}

Between 1997 and 2002, we collected fresh leaves from 87 and 37 individuals of Asplenium nidus in the Malay Peninsular and West Sumatra, respectively. We also collected fresh leaves from 26 individuals in West Java in addition to the 40 individuals in a previous study (Yatabe et al. 2002). For all the individuals collected from West Java and West Sumatra, and 73 individuals collected from the Malay Peninsula, we recorded their habitats, such as altitude and position on the tree trunk where they grew. Details of the localities are provided in Table 2. We used small parts of fresh leaves for $r b c \mathrm{~L}$ sequencing and kept the rest as vouchers in the herbarium of the Graduate School of Science, Kyoto University (KYO). Full voucher details will be available on completion of the project.

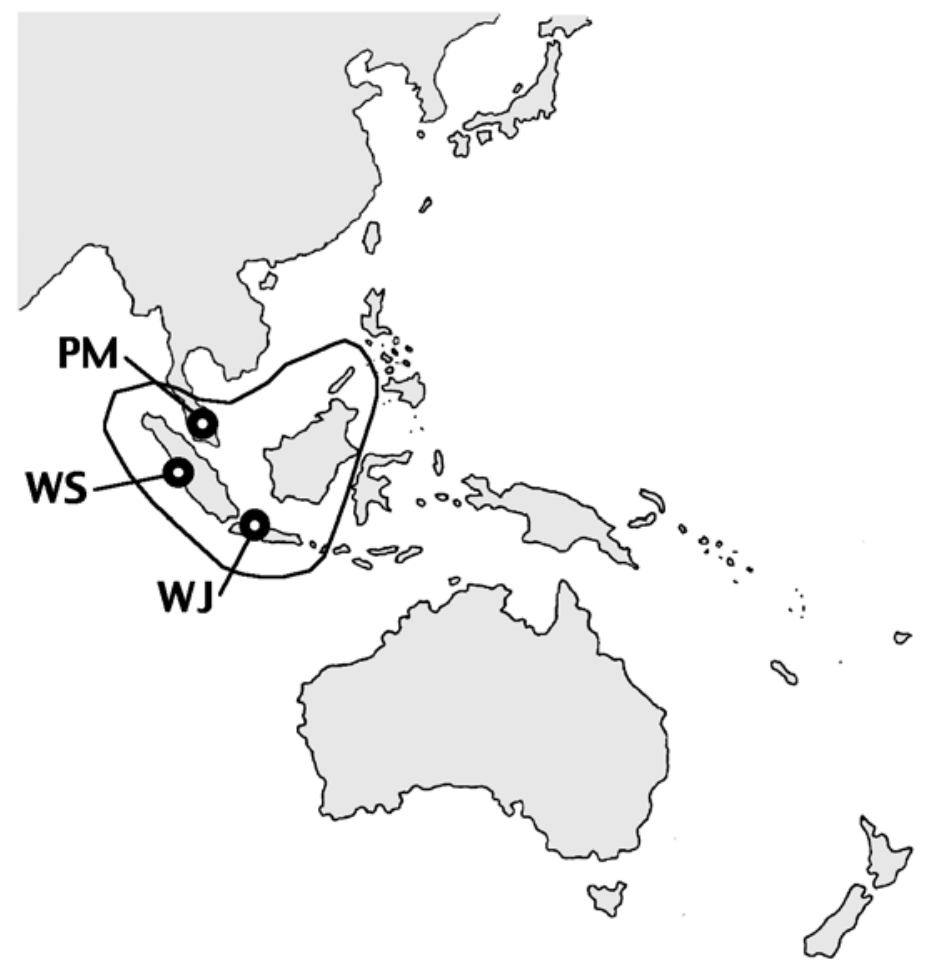

Fig. 1. Map of the West Malesian region. WJ, West Java, WS, West Sumatra, PM, Malay Peninsula. 


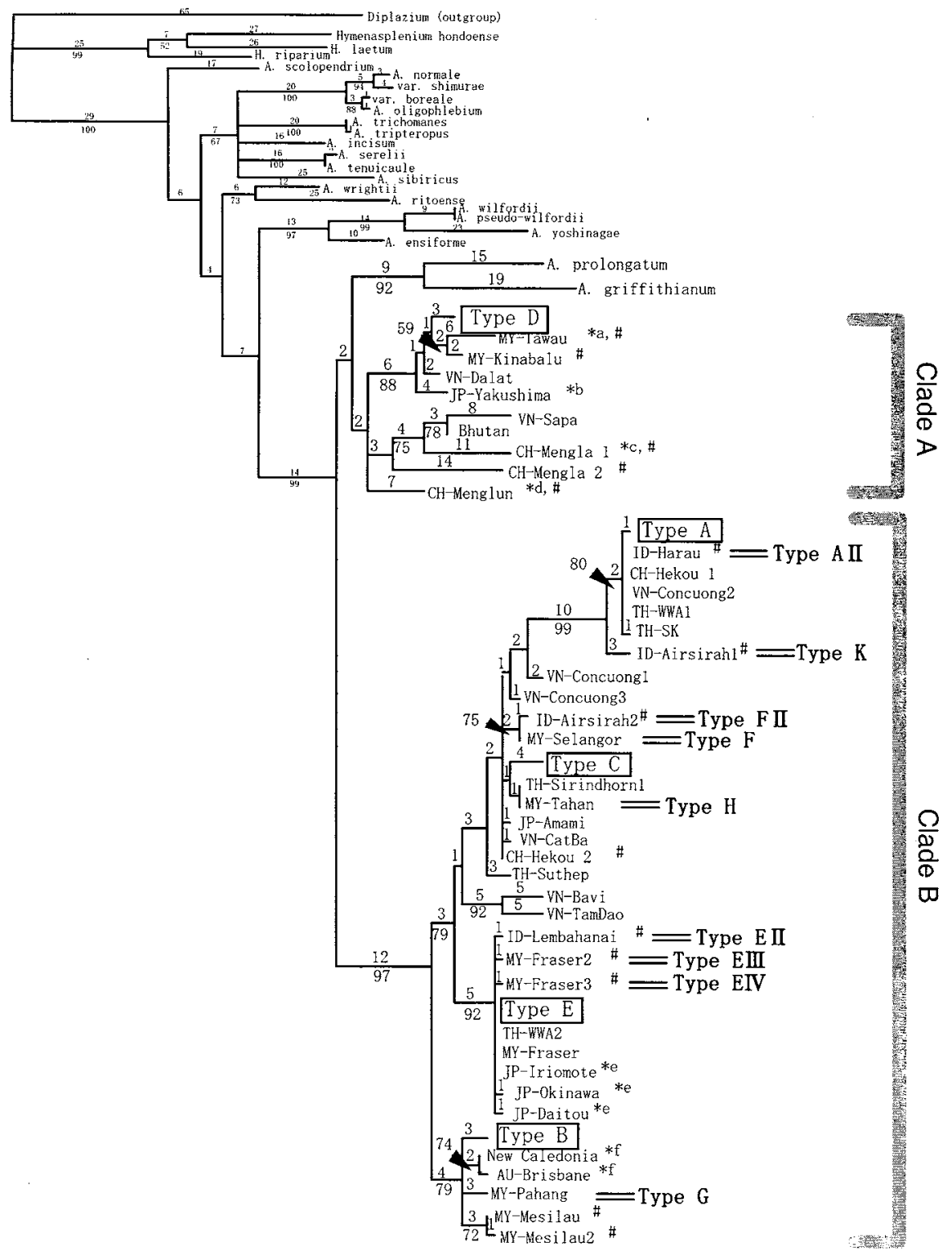

Fig. 2. The strict consensus of the four most parsimonious trees (length $=700$ steps; consistency index $=0.587$; retention index $=0.815$ ) obtained in the phylogenetic analysis using PAUP ver. 3.1.1 based on the $r b c \mathrm{~L}$ sequence data of Asplenium sect. Thamnopteris. Information on each accession is available in Yatabe et al. (2001) except for those indicated by \#. The numbers above and below the branches are the number of nucleotide substitutions (ACCTRAN optimisation) and bootstrap percentages respectively. ${ }^{* a}$ is identified as A. cymbifolium; ${ }^{*} \mathrm{~b}$ as $A$. antiquum; ${ }^{*} \mathrm{c}$ as A. phyllitidis; ${ }^{*} \mathrm{~d}$ as $A$. antrophyoides; ${ }^{*}$ e as $A$. setoi; ${ }^{*}$ as $A$. australasicum. 
Table 2. $R b c L$ sequence type and the number of individuals of each $r b c L$ sequence type found in the West Malesia region.

\author{
Locality \\ individuals) \\ West Java \\ Halimun National Park, West Java, Indonesia* \\ Gunung Gede Pangrangro National Park, West Java \\ Bogor Botanical Garden, West Java* \\ $A(n=16), B(n=10), C(n=15), D(n=8), E(n=4)$ \\ $C(n=22), D(n=8)$ \\ $E(n=5)$ \\ Malay Peninsular \\ Cameron Highland, Malaysia \\ Fraser's Hill, Malaysia \\ Mt. Tahan, Malaysia \\ Kuala Lumpur

$$
\begin{aligned}
& \text { All }(n=1), E(n=17), F(n=27), G(n=9), H(n=5) \\
& \text { All }(n=3), E(n=12), E I I(n=1), E I V(n=1), \\
& F(n=5), G(n=2) \\
& E(n=1), F(n=1) \\
& G(n=2)
\end{aligned}
$$ \\ West Sumatra \\ within a radius of $50 \mathrm{~km}$ from Padang City, \\ West Sumatra, Indonesia \\ All $(n=2), E(n=11), E I I(n=1), F(n=12)$, \\ FII $(n=1), G(n=3), K(n=4)$ \\ Lembah Harau Natural Reserve, \\ West Sumatra, Indonesia \\ All $(n=2), E(n=3)$ \\ *indicates the data provided in the previous study (Yatabe et al. 2002)
}

\section{RbcL sequencing}

Total DNA was extracted using a 2X CTAB (hexadecyl trimethyl ammonium bromide) solution according to the method of Doyle and Doyle (1987). PCR (polymerase chain reaction) amplification of $r b c L$ fragments followed Murakami et al (1999a). The PCR products were purified using a GENE CLEAN III kit (BIO101, Vista, California, USA) after electrophoresis in $1.0 \%$ agarose gel, and then used as templates for direct sequencing. Sequencing reactions were prepared using a Big Dye terminator cycle sequencing kit (Perkin Elmer Applied Biosystems, Foster, California, USA). The reaction mixtures were analyzed on an Applied Biosystems Model 377 automated sequencer (Perkin Elmer Applied Biosystems). For phylogenetic analyses, sequences were aligned using Sequence Navigator Software (Perkin Elmer Applied Biosystems). GenBank numbers will be published on completion of the project.

\section{Phylogenetic analysis}

The $r b c \mathrm{~L}$ sequence data matrix contained data from 68 accessions, including that of Diplazium esculentum and those of 22 species in Aspleniaceae other than those of the Asplenium nidus complex. Diplazium esculentum (Woodsiaceae) was used as the outgroup. Phylogenetic analysis was performed by the Maximum Parsimony method using PAUP (Phylogenetic Analysis Using Parsimony) version 3.1.1 (Swofford 1993). A branch and bound search was conducted to find the most parsimonious trees. A bootstrap analysis with 10000 replications was performed in order to estimate the reliability for various clades. 


\section{Results}

\section{RbcL types in West Java, Peninsular Malaysia and West Sumatra}

We determined $r b c L$ nucleotide sequences of $1194 \mathrm{bp}$ for a total of 192 individuals and found $14 \mathrm{rbcL}$ types including the five types reported from West Java - Types A, B, C, D and E. We named the other types as Type AII, EII, EIII, EIV, F, FII, G, H, and K. The number of individuals of each $r b c \mathrm{~L}$ type found from each locality are shown in Table 2. We found only a small number of individuals, one to four, of Type EII, EIII, EIV, FII, H and K. In Mt. Gede, West Java, we found two types, Type C and D, which had been already found from Mt. Halimun National Park. In the Malay Peninsular and West Sumatra, seven and six types were found, respectively. Four types, AII, E, F and G, were distributed in both the Malay Peninsular and West Sumatra. While Type E was found from the Malay Peninsular and West Sumatra as well as West Java, the other four types reported from West Java (A, B, C and D) have not been found from these other areas.

\section{Phylogenetic analysis}

For phylogenetic analysis, we used 1191 nucleotide characters because the outgroup did not show 1194 bp nucleotides. This gave 75 equally most parsimonious trees (length $=700$ steps; consistency index $=0.587$; retention index $=0.815$ ). The strict consensus tree with bootstrap percentages is shown in Fig. 2. The general topology of the tree for Aspleniaceae is the same as that in Murakami et al. (1999c). The plants identified as Asplenium nidus were, however, not supported as a monophyletic group because $A$. griffithianum and $A$. prolongatum were nested within the $A$. nidus complex (Fig. 2). In $A$. nidus two major clades were formed, one clade (Clade B) which has high bootstrap support (97\%), includes A. australasicum from New Caledonia and Australia, $A$. setoi from Japan and $A$. nidus from various localities in Asia (Fig. 2). The sequence of $A$. setoi from Iriomote Is. is the same as that of Type E. The other clade (Clade A) which is closely associated with $A$. griffithianum and $A$. prolongatum, includes A. antiquum from Japan, A. cymbifolium from West Malesia, A. phyllitidis and $A$. antrophyoides from China, and some populations of $A$. nidus from Asia, including West Malesia, Bhutan and Vietnam (Fig. 2).

\section{Ecological observation}

The altitude where the individuals grew, and the distribution of each $r b c \mathrm{~L}$ type in West Java, Peninsular Malaysia and West Sumatra, is shown in Figs 3, 4 and 5, respectively. On Mt. Gede, West Java, at altitudes above $1400 \mathrm{~m}$, we found the two types, Type C and D, which had been found above 1300m in Mt. Halimun National Park, West Java (Fig. 3). In Mt. Gede and Mt. Halimun National Park, Type D was not found below $1600 \mathrm{~m}$ (Fig. 3). Type C and D were not found in the Malay Peninsula or West Sumatra.

Type E, found in areas lower than $1100 \mathrm{~m}$ alt. in West Java, was found in the Malay Peninsula and West Sumatra. In the Malay Peninsula or West Sumatra, Type E was not found above 1200m (Figs 4,5). Besides Type E, Type AII, F and G were found in both the Malay Peninsula and West Sumatra. All but one individual of Type G were found at altitudes lower than $600 \mathrm{~m}$, and the only individual found at $1100 \mathrm{~m}$ in Cameron Highland, the Malay Peninsula, was a sterile plant without sori (Fig. 4). Type AII was found at altitudes below 1000m (Figs 4, 5) and always grew on tree trunks below the $2 \mathrm{~m}$ level. In striking contrast to Types AII, E and G, Type F was found at higher elevations in the Malay Peninsula and West Sumatra (Figs 4, 5). 


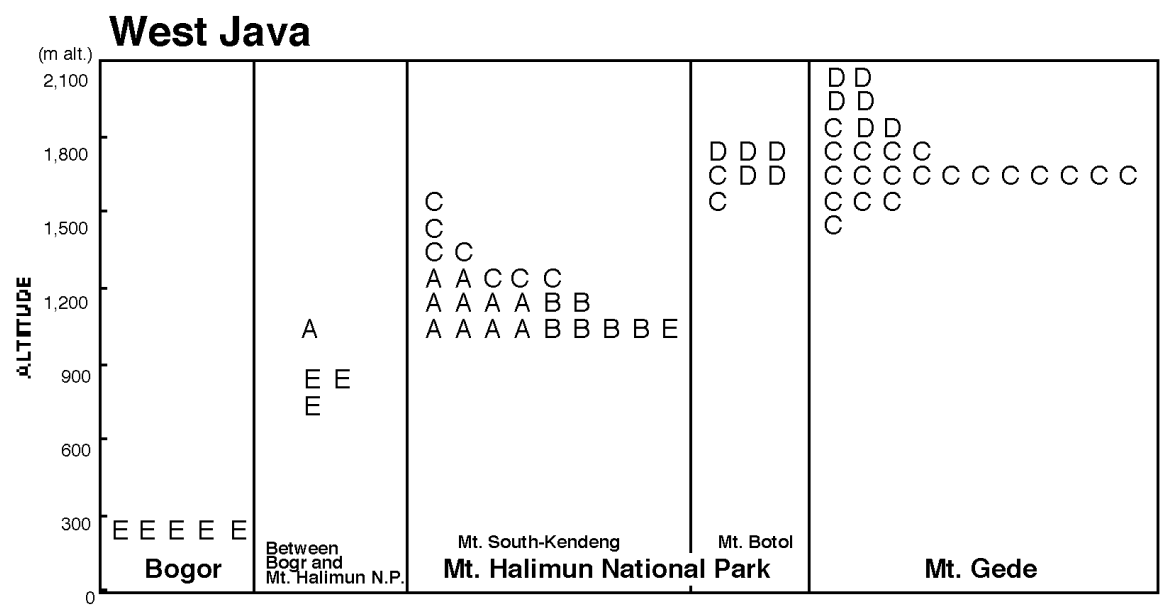

Fig. 3. The distribution of each $r b c \mathrm{~L}$ type in West Java. The $r b c \mathrm{~L}$ type is indicated for each individual examined. Each $r b c \mathrm{~L}$ type is concordant with those in Fig. 1.

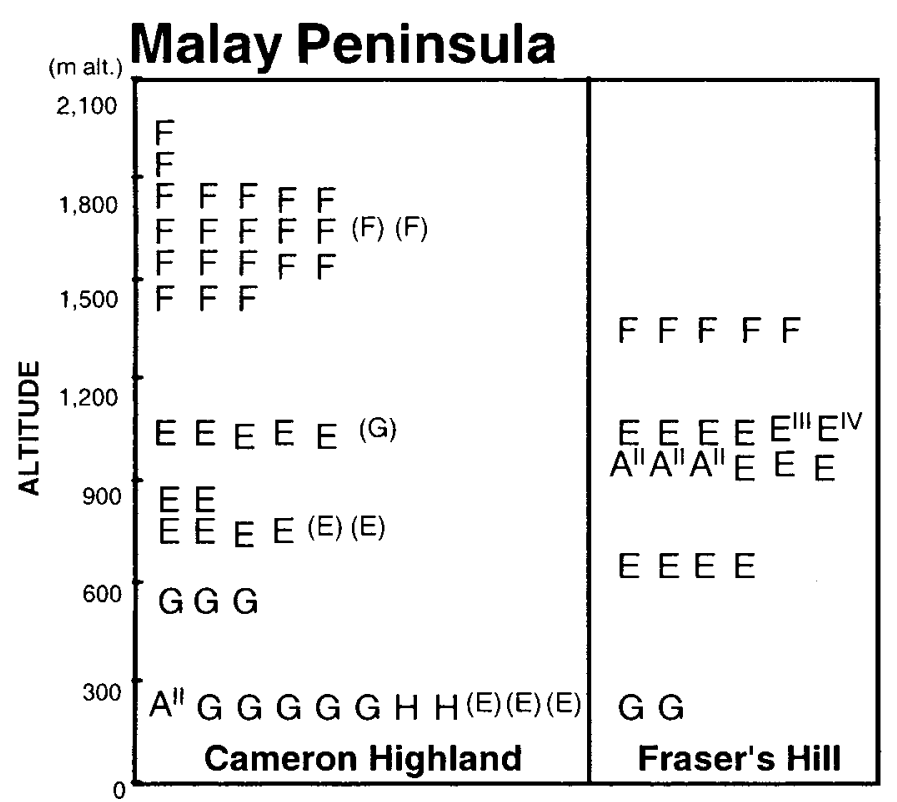

Fig. 4. The distribution of each $r b c \mathrm{~L}$ type in the Malay Peninsula. The $r b c \mathrm{~L}$ type is indicated for each individual examined. Parentheses indicate the individuals that lack sori. Each $r b c \mathrm{~L}$ type is concordant with those in Fig. 1. 


\section{Discussion}

DNA sequence data have been used for analysing phylogenetic relationships among species, or higher taxa. In particular, maternally inherited chloroplast DNA was considered to be appropriate for phylogenetic analysis from many aspects. One of the superior features of chloroplast DNA is its small effective population size, which is one quarter of that of nuclear DNA. Since genetic drift excludes genetic variation from a gene pool more effectively in chloroplast DNA than in nuclear DNA, it is less feasible that ancestral polymorphism and lineage sorting cause disagreement between a gene tree and a species tree (Moore 1995). In recognising reproductively isolated assemblages, chloroplast DNA, where variations are efficiently excluded, may provide appropriate information as well. In previous studies, using $r b c \mathrm{~L}$ sequences as the first step, we recognized five potential cryptic species in the populations of Asplenium nidus in Mt. Halimun National Park and the surrounding area (Murakami et al. 1999b, Yatabe et al.2001, Yatabe et al. 2002). It was suggested that these potential cryptic species would be ecologically and genetically differentiated, and some pairs of them have been already tested for reproductive isolation by artificial crossing experiments. Thus, $r b c \mathrm{~L}$ sequences may be useful as a first step in revealing cryptic species hiding in the populations of $A$. nidus at particular localities.

It is, however, necessary to take allopatric populations into consideration as well as sympatric and parapatric populations in order to evaluate species diversity in Asplenium sect. Thamnopteris. As a result of our investigations in the Malay Peninsula and West Sumatra show, Type E turns out to be widely distributed in lowland areas of West Malesia. In addition to this the $r b c \mathrm{~L}$ sequence of $A$. setoi from Iriomote Is. was found to be the same as that of Type E. In order to clarify the relationship between $A$. setoi distributed in Japan and Type E found from West Malesia, further investigations, such as artificial crossing experiments and morphological comparisons, will be required. The other four types found from West Java, Type A, B, C and D, have not

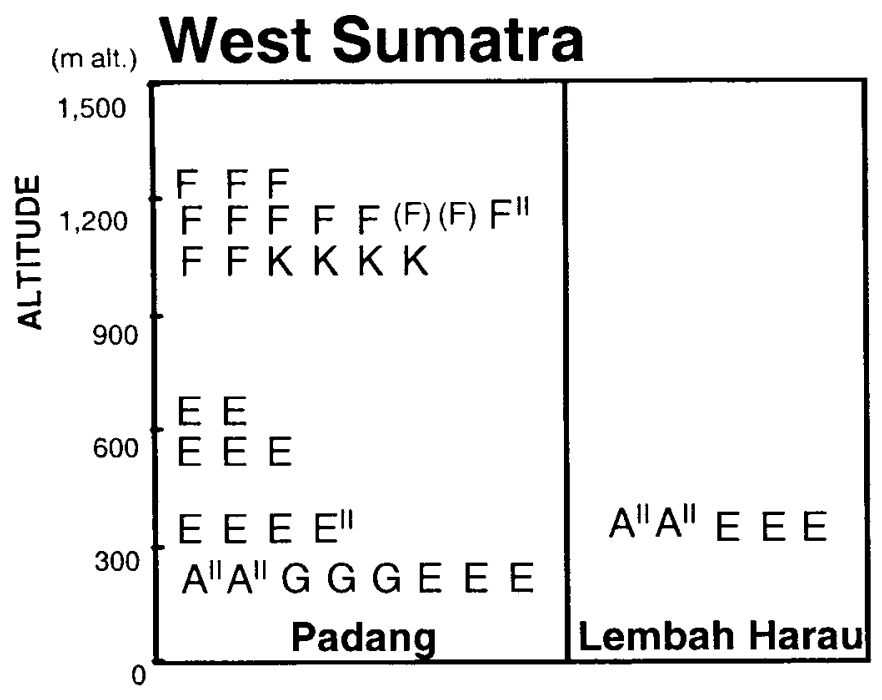

Fig. 5. The distribution of each $r b c \mathrm{~L}$ type in West Sumatra. The $r b c \mathrm{~L}$ type is indicated for each individual examined. Parentheses indicate the individuals that lack sori. Each $r b c \mathrm{~L}$ type is concordant with those in Fig. 1. 
been found outside West Java. Therefore, the geographical distributions of these four potential cryptic species are still unknown.

In the Malay Peninsula and West Sumatra, we also investigated the habitat in the same way as we did in West Java (Murakami et al. 1999b, Yatabe et al. 2002, Fig.2). In West Java, the habitats were well differentiated between the five $r b c \mathrm{~L}$ types in altitude or in position on the tree, though the boundaries of the habitat were not necessarily clear. Also in the Malay Peninsula and West Sumatra, differences in habitat among rbcL types were observed. The four types, Type AII, E, F and G, were distributed in both Peninsular Malaysia and West Sumatra (Table 2). The habitat of Type F was suggested to differ in altitude from the other three types, Type AII, E and G (Figs 4, 5). The difference in habitat between Type $F$ and the other three types was clear because Type $\mathrm{F}$ was never found at the same elevation as the other three types. Type F was, however, found together with Type FII in the Malay Peninsula and with Type $K$ in West Sumatra, so ecological comparison will be required between these sympatrically distributed pairs of $r b c \mathrm{~L}$ types. Ecological differentiation between Type $\mathrm{E}$ and $\mathrm{G}$ was obscure because these two types were sometimes found together at the same elevation. As far as the distribution of mature individuals of these two $r b c \mathrm{~L}$ types is concerned, Type $G$ has an inclination to grow at a lower elevations than Type E does (Figs 4,5$)$. When we take it into consideration that an immature plant was found at an altitude of $1100 \mathrm{~m}$ in the Malay Peninsula (Figs. 4), it is possible that Type G may grow well at lower elevations than Type E. In Halimun National Park, West Java, between Type A and B, difference in the position where they grow on tree trunks was reported, and Type A was suggested to prefer deeply shaded places (Murakami et al. 1999b). Comparing the three types, Type E, F and G, with Type AII in the Malay Peninsula and West Sumatra, Type AII grew on relatively low sections of tree trunk where it is deeply shaded. Therefore, it is suggested that Type AII also may prefer deeply shaded places. Thus, ecological differentiation was observed between some pairs of $r b c \mathrm{~L}$ types also in the Malay Peninsula and West Sumatra. Moreover, as far as Type AII, E, F and G are concerned, it is suggested that individuals of the same $r b c \mathrm{~L}$ type may not differ in their habitat preference between the Malay Peninsula and West Sumatra.

In order to understand species diversity in Asplenium sect. Thamnopteris, it will be necessary to increase investigation localities and to continue recognizing potential cryptic species by analyzing molecular data, such as $r b c \mathrm{~L}$ sequence and allozymes, and ecological comparison. Crossing experiments will also be required to investigate reproductive isolation among potential cryptic species. At present we are conducting artificial crossing experiments between various pairs of $r b c \mathrm{~L}$ types collected widely from the West Malesian region and other localities, including not only the plants identified as Asplenium nidus but also related species in Asplenium sect. Thamnopteris. Once we obtain hybrid plants, we will grow them in order to examine their fertility. These kinds of data will provide more information on the systematics of Asplenium sect. Thamonopteris.

\section{Acknowledgments}

The authors thank Dedy Darnaedi and the other staff members of Bogor Botanical Gardens, Indonesian Institute of Science and Mt. Halimun National Park for their kind assistance in our collection of plant materials; Prof. K. Iwatsuki, The University of The Air, for his valuable advice and generous support; and Dr. M. Watanabe, Aichi Kyoiku University, for his instructions for allozyme analyses. This study was supported in part by Grants-in-Aid Number 1203497 (to YY), 11440246 (to NM) and 13575012 (to NM) from the Japan Society for the Promotion of Science. 


\section{References}

Abraham, A., Ninan, C.A. \& Mathew, P.M. (1962) Studies on the cytology and phylogeny of the pteridophytes. VII. Observations on one hundred species of south Indian ferns. J. Indian Bot. Soc. 41: 339-421.

Bir, S.S. (1960) Cytological observations on the East Himalayan members of Asplenium Linn. Curr. Sci. 29: 445-447.

Doyle, J.J., Doyle, J.L. (1987) A rapid DNA isolation procedure for small quantities of fresh leaf tissue. Phytochemistry 19:11-15.

Holltum, R.E. (1974) Asplenium Linn, sect. Thamnopteris Presl. Gard. Bull. Singapore 27: 143-154.

Kato, M., Yatabe, Y., Sahashi, N. \& Murakami, N. (2001) Taxonomic studies of Cheiropleuria (Dipteridaceae). Blumea 46:53-525.

Kawakami, S. (1970) Karyological studies on Aspleniaceae. II. Chromosomes of seven species in Aspleniaceae. Bot. Mag. Tokyo 83: 74-81.

Koul, A.K. (1970) Supernumerary cell divisions following meiosis in the spider plant. Genetica 41: 305-310.

Moore, W.S. (1995) Inferring phylogenies from mtDNA variation: Mitochondrial-gene trees versus nuclear-gene trees. Evolution 49: 718-726.

Murakami, N., Yokoyama, J., Cheng, X., Iwasaki, H., Imaichi, R. \& Iwatsuki. K. (1998a) Molecular taxonomy of Hymenasplenium obliquissimum complex (Aspleniaceae) based on rbcL sequence comparisons. Plant Species Biol. 13: 51-56.

Murakami, N., Yokoyama, J. \& Iwatsuki K. (1998b) Hymenasplenium inthanonense (Aspleniaceae), a New Fern Species from Doi Inthanon, and its phylogenetic status. Thai Forest Bull. 26: 40-52.

Murakami, N., Yokoyama, J., Yatabe, Y., Iwasaki, H. \& Serizawa, S. (1999a) Molecular taxonomic study and revision of the three Japanese species of Asplenium sect. Thamnopteris. J. Plant Res. 112: 15-25.

Murakami, N., Yatabe, Y., Iwasaki, H., Darnaedi, D. \& Iwatsuki, K. (1999b) Molecular $\alpha$-taxonomy of a morphologically simple fern Asplenium nidus complex from Mt. Halimun National Park, Indonesia, Pp. 53-66. In M. Kato (ed.), The biology of biodiversity. (Springer-Verlag: Tokyo).

Murakami, N., Nogami, S., Watanabe, M. \& Iwatsuki, K. (1999c) Phylogeny of Aspleniaceae inferred from $r b c L$ nucleotide sequences. Amer. Fern J. 89: 232-243.

Paris, C.A., Wagner, F.S. \& Wagner, H. W. (1989) Cryptic species, species delimitation, and taxonomic practice in the homosporous ferns. Amer. Fern J. 79: 46-54.

Soltis, D.E. \& Soltis, P.S. (1989) Isozymes in plant biology. (Chapman and Hall: London).

Swofford, D.L. (1993) Phylogenetic analysis using parsimony, version 3.1. User's manual. (Illinois Natural History Survey: Champaign, Illinois, USA).

Tsai, J.L. \& Shieh, W.C. (1983) A cytotaxonomic survey of the pteridophytes in Taiwan. J. Sci. 20: $137-158$.

Yatabe, Y., Takamiya, M. \& Murakami, N. 1998. Variation in the rbcL sequence of Stegnogramma pozoi subsp. mollissima (Thelypteridaceae) in Japan. J. Plant Res. 111: 557-564.

Yatabe, Y., Nishida, H. \& Murakami, N. (1999) Phylogeny of Osmundaceae inferred from rbcL nucleotide sequence and comparison to the fossil evidences. J. Plant Res. 112: 397-404.

Yatabe, Y., Masuyama, S., Darnaedi, D. \& Murakami, N. (2001) Molecular systematics of the Asplenium nidus complex from Mt. Halimun National Park, Indonesia. Evidence for reproductive isolation among three sympatric $r b c \mathrm{~L}$ sequence types. 2001. Amer. J. Bot. 88: $1517-1522$.

Yatabe, Y., Darnaedi, D. \& Murakami, N. (2002) Allozyme analysis of cryptic species in the Asplenium nidus complex from West Java, Indonesia. J. Plant Res. 115: 483-490. 